\title{
Spread of extended-spectrum beta-lactamase producing Escherichia coli isolates in Swedish broilers mediated by an incl plasmid carrying bla $a_{\mathrm{CTX}-\mathrm{M}-1}$
}

Stefan Börjesson ${ }^{1 *}$, Björn Bengtsson ${ }^{1}$, Cecilia Jernberg ${ }^{2}$ and Stina Englund ${ }^{1}$

\begin{abstract}
Background: The already high and increasing occurrence of extended-spectrum beta-lactamases (ESBL) producing Escherichia coli in European broiler populations is of concern due to the fact that third and fourth generation cephalosporins are deemed critically important in human medicine. In Sweden 34\% of the broilers carry ESBL/ pAmpC producing E. coli in their gut, despite the absence of a known selection pressure such as antimicrobial usages. The aim of the current study was to characterise a selection of $E$. coli strains carrying the bla $a_{\mathrm{CTX}-\mathrm{M}-1 \text {, to }}$ determine if the spread was due to a specific clone.
\end{abstract}

Findings: Ten isolates carrying bla $a_{\mathrm{CTX}-\mathrm{M}-1}$ from Swedish broilers belonged to eight different multi-locus sequence types with three isolates belonging to ST155. The ST155 isolates were identical as assessed by PFGE. The bla $a_{\mathrm{CTX}-\mathrm{M}-1}$ was in all isolates carried on a plasmid of replicon type incl, which also transferred resistance to tetracycline and sulfamethoxazole.

Conclusion: The occurrence of ESBL-producing E. coli in the Swedish broilers is not due to the emergence of a single clone, but rather the spread of a specific incl plasmid carrying bla $a_{\mathrm{CTX}-\mathrm{M}-1}$.

Keywords: Extended spectrum betalactamases, ESBL, Broiler, CTX-M-1, Escherichia coli

\section{Findings}

The increasing trend of extended-spectrum beta-lactamases (ESBL) and plasmid-mediated AmpC (pAmpC) producing Escherichia coli in food-producing animals worldwide is worrisome $[1,2]$ due to the significance of third and fourth generation cephalosporins in human medicine. The European Food Safety Authority concluded in a recent report that there exist evidence that food-producing animals can be a reservoir for ESBL and pAmpC producing Enterobacteriaceae and the corresponding genes and that transmission has occurred between foodproducing animals and humans [3]. The report also highlighted that the high and increasing prevalence in broiler and broiler meat is of particular concern. In addition, a

\footnotetext{
* Correspondence: stefan.borjesson@sva.se

'Department of Animal health and Antimicrobial strategies, National Veterinary Institute (SVA), Uppsala SE-751 89, Sweden

Full list of author information is available at the end of the article
}

recent study from the Netherlands concluded that identical ESBL producing E. coli isolates, plasmids and genes occurred both in broiler, meat and humans [4]. It has been suggested that the reason for the increasing occurrence of ESBL and pAmpC producing Enterobacteriaceae in broilers is due to the use of cephalosporins [5]. However, the total sales of third generation cephalosporins devoted to Swedish animals in 2009 constituted $\sim 20 \mathrm{~kg}, 0.001 \%$ of total sales of veterinary antimicrobials, and they were mainly prescribed to horses and cattle [6]. Therefore it was highly surprising when in $201034 \%$ of broilers in Sweden were found to carry ESBL or pAmpC producing E. coli using selective cultivation methods [7]. There were only two genes identified $b l a_{\mathrm{CTX}-\mathrm{M}-1}$ and $b l a_{\mathrm{CMY}-2}$, with $b l a_{\mathrm{CMY}-2}$ clearly dominating. This genotype composition differs from that in most other European countries [3]. Other European countries than Sweden generally have a higher diversity of genotypes on their broiler farms and a

\section{Ciomed Central}

(c) 2013 Börjesson et al.; licensee BioMed Central Ltd. This is an Open Access article distributed under the terms of the Creative Commons Attribution License (http://creativecommons.org/licenses/by/2.0), which permits unrestricted use, distribution, and reproduction in any medium, provided the original work is properly cited. 
much lower prevalence of $b l a_{\mathrm{CMY}-2}$, but $b l a_{\mathrm{CTX}-\mathrm{M}-1}$ appear to be common in broilers in most countries. A selection of $E$. coli isolates carrying bla $a_{\mathrm{CMY}-2}$ was characterised and compared to human clinical isolates in a previous study [8]. It was shown that the occurrence of $b l a_{\mathrm{CMY}-2}$ was not due to the spread of a single clone and that transmission to humans appears very limited and restricted to the plasmids. In the current study we characterised a selection of bla $a_{\mathrm{CTX}-\mathrm{M}-1}$ E. coli isolates from Swedish broilers and compared the results in a European context.

Ten isolates carrying bla $a_{\mathrm{CTX}-\mathrm{M}-1}$ from Swedish broilers (collected February-May 2010) were obtained through the Swedish program for monitoring antimicrobial resistance in the veterinary field (SVARM) [7]. Isolates were obtained by culturing ceacal samples on MacConkey agar with $1 \mathrm{mg} / \mathrm{L}$ cefotaxime. All isolates were multi-resistant, i.e. resistant to three or more antimicrobial classes. The isolates were characterised using Pulsed field gel electrophoresis (PFGE) [9], Multilocus sequence typing (MLST) (http://mlst.ucc.ie/) and Polymerase Chain Reaction (PCR) based plasmid replicon typing [10]. For comparison of PFGE pattern DICE coefficient and UPGMA cluster analysis was performed, with position tolerance and optimisation both set at $1 \%$. Transferability of bla $a_{\mathrm{CTX}-\mathrm{M}-1}$ was tested through conjugation to $E$. coli HMS174. Transformation was performed on transconjugants PCR positive for multiple plasmid replicon types. Plasmid DNA was extracted according to the protocol by Sambrook and Russell [11] with minor modifications and transformed into ElectroMax ${ }^{\text {тм }} \mathrm{DH} 10 \mathrm{~B}^{\mathrm{TM}}$ (Gibco Invitrogen, Carlsbad, CA, USA) according to the manufacturer's instructions, voltage changed to $1250 \mathrm{~V}$. Transconjugants and transformants were tested for antimicrobial susceptibility using VetMIC GN-mo microdilution plates with epidemiological cut-off value set by EUCAST (SVA, Uppsala, Sweden), for ESBL genes [12] and plasmid replicon types.

The 10 isolates belonged to eight different STs, with ST155 (3 isolates) being the most common (Table 1). Nine isolates were typeable using PFGE and 1 was nontypeable. All isolates were able to transfer $b l a_{\mathrm{CTX}-\mathrm{M}-1 \text {. In }}$ addition to the ESBL phenotype, all isolates transferred resistance to sulfamethoxazole and tetracycline and one also transferred streptomycin resistance. It was found that the transconjugants contained plasmids belonging to the IncI replicon type. However, five transconjugants were also PCR positive for multiple plasmids replicon types and these five were subjected to transformation. The resulting transformants were all positive for the IncI replicon type and resistant to sulfamethoxazole and tetracycline. Transformation on a transconjugant positive for IncI verified that the IncI plasmid carried bla $a_{\mathrm{CTX}-\mathrm{M}-1}$ and sulfamethoxazole and tetracycline resistance phenotype.
Table 1 Escherichia coli isolates carrying bla obtained from broiler chickens characterized by multi locus sequence types (MLST), Pulsed field gel electrophoresis (PFGE) and resistance patterns determined using VetMIC GN-mo microdilution plates

\begin{tabular}{lll}
\hline MLST (clonal complex) & Resistance pattern & $\begin{array}{l}\text { No. of } \\
\text { isolates }\end{array}$ \\
\hline ST57 (CC350) & SuTC & 1 \\
ST135 (N.D. $)^{\text {B }}$ & SuTC & $1^{C}$ \\
ST155 (CC150) & SuTC & $3^{D}$ \\
ST219 (N.D.) & SuTC & $1^{\mathrm{E}}$ \\
ST602 (CC446) & SmSuTC & $1^{C}$ \\
ST752 (CC10) & SmSuTC & 1 \\
ST1594 (N.D.) & SuTC & 1 \\
ST1640 (CC350) & SmSuTC & 1
\end{tabular}

${ }^{A}$ Determined in a previous study [7], Su = sulphamethoxazole, Tc = tetracycline, $\mathrm{Sm}=$ streptomycin ${ }^{\mathrm{B}} \mathrm{N} . \mathrm{D}$. = not determined ${ }^{\mathrm{C}}$ Assigned to the same PFGE-cluster

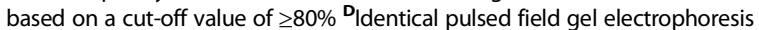
(PFGE) patterns ${ }^{\mathrm{E}}$ Non-typeable by PFGE using Xbal.

The results show that the occurrence of ESBL producing E. coli in the Swedish broiler population is, like the pAmpC producing E. coli [8], not due to one specific clone but appears to be connected to a specific incI plasmid also carrying resistance to sulfamethoxazole and tetracycline. It is well-established that bla $a_{\mathrm{CTX}-\mathrm{M}-1}$ on IncI plasmids are frequently isolated both in the poultry industry and in human clinical settings in Europe [2]. In a study from the Netherlands it was also the IncI plasmids carrying bla $a_{\mathrm{CTX}-\mathrm{M}-1}$ that dominated and the plasmids were found to be identical in isolates of human and broiler origin [4]. Furthermore, genetically related bla $a_{\mathrm{CTX}-\mathrm{M}-1}$-IncI plasmids from human and broiler isolates have also been described in France [13]. It is therefore possible that the Swedish broiler population can be a potential source for these plasmids and genes in human clinical settings. However, to establish if this is the case, further and more extensive studies should be carried out.

Because the incI plasmid carries phenotypical resistance to tetracycline and sulfamethoxazole, usage of these antibiotics, in addition to use of cephalosporins and other B-lactam antibiotics, may facilitate the spread of the plasmid. Previous studies have also suggested that co-resistance has played a role in the rapid emergence of ESBL producing bacteria [2]. However, the occurrence in Sweden of ESBL, nor pAmpC, producing E. coli cannot be explained by antibiotic usage because this usage is very limited. For example, in 2011 only 6 of 3185 broiler flocks were treated with antibiotics and no cephalosporins were prescribed [14]. A likely explanation to the high occurrence can be a top-down transmission from imported grand-parent birds. The potential for transmission of cephalosporin-resistant $E$. coli, along with 
quinolone-resistant isolates, through the production pyramid has been suggested in earlier studies $[15,16]$. This theory is further supported by a pilot study that identified $E$. coli carrying bla $a_{\mathrm{CMY}-2}$ and/or bla $a_{\mathrm{CTX}-\mathrm{M}-1}$ in the environment at production hatcheries and in breeding stocks in Sweden [7]. The high occurrence in Swedish broiler might also be maintained by transmission between flocks. However, the Swedish broiler houses are cleaned and disinfected between batches therefore this type of contribution is probably low.

\section{Conclusions}

The presence of ESBL producing E. coli in the Swedish broiler population is not due to the emergence of one specific clone but seems to be due to the spread of one plasmid, an incI plasmid carrying $b l a_{\mathrm{CTX}-\mathrm{M}-1}$ and resistance to tetracycline and sulfamethoxazole.

\section{Competing interests}

The authors declare that they have no competing interests.

\section{Authors' contributions}

SB participated in the design of the study, carried out the analyses and drafted the manuscript. BB participated in the design of the study and assisted and in the drafting of the manuscript. CJ carried out the PFGEanalyses. SE participated in the design of the study helped to draft the manuscript and carried out the analyses. All authors have read, participated in and approved the final manuscript.

\section{Acknowledgments}

Anthony Österdahl, SVA, Uppsala is acknowledged for comments and linguistic revision of the manuscript. This work was supported by The Swedish Civil Contingencies Agency.

\section{Author details}

${ }^{1}$ Department of Animal health and Antimicrobial strategies, National Veterinary Institute (SVA), Uppsala SE-751 89, Sweden. ${ }^{2}$ Department of Preparedness, Swedish Institute for Communicable Disease Control (Nobelsväg 18), Solna 17182, Sweden.

Received: 31 October 2012 Accepted: 15 January 2013

Published: 21 January 2013

\section{References}

1. Dierikx C, van Essen-Zandbergen A, Veldman K, Smith H, Mevius D: Increased detection of extended spectrum beta-lactamase producing Salmonella enterica and Escherichia coli isolates from poultry. Vet Microbiol 2010, 145:273-278.

2. Naseer $U$, Sundsfjord A: The ctx-m conundrum: dissemination of plasmids and Escherichia coli clones. Microb Drug Resist 2011, 17:83-97.

3. EFSA: Scientific opinion on the public health risks of bacterial strains producing extended-spectrum $\beta$-lactamases and/or ampc $\beta$-lactamases in food and food-producing animals. EFSA J 2011, 9:2322.

4. Leverstein-van Hall MA, Dierikx CM, Cohen Stuart J, Voets GM, van den Munckhof MP, van Essen-Zandbergen A, Platteel T, Fluit AC, van de SandeBruinsma N, Scharinga J, Bonten MJ, Mevius DJ: Dutch patients, retail chicken meat and poultry share the same ESBL genes, plasmids and strains. Clin Microbiol Infect 2011, 17:873-880.

5. Dutil L, Irwin R, Finley R, Ng LK, Avery B, Boerlin P, Bourgault AM, Cole L, Daignault D, Desruisseau A, Demczuk W, Hoang L, Horsman GB, Ismail J, Jamieson F, Maki A, Pacagnella A, Pillai DR: Ceftiofur resistance in salmonella enterica serovar heidelberg from chicken meat and humans, Canada. Emerg Infect Dis 2010, 16:48-54.

6. Grave K, Greko G, Kvaale MK, Torren-Edo J, Mackay D, Muller A, Moulin G: Sales of veterinary antibacterial agents in nine European countries during 2005-2009: trends and patterns. J Antimicrob Chemother 2012, 67:3001-3008

7. Bengtsson B, Ericsson-Unnerstad H, Greko G, Grönlund-Andersson U, Landén A: Swedish Veterinary Antimicrobial Resistance Monitoring (SVARM) 2010. Uppsala: National Veterinary Institute (SVA); 2011.

8. Börjesson $S$, Jernberg $C$, Brolund $A$, Edquist $P$, Finn $M$, Landén A, Olsson Liljequist P, Tegemark-Wisell K, Bengtsson B, Englund S: Characterisation of plasmid-mediated AmpC-producing E. coli isolated from Swedish broilers and association to human clinical isolates. Clin Microbiol Infect 2013, In Press.

9. Maslow JN, Mulligan ME, Arbeit RD: Molecular epidemiology: application of contemporary techniques to the typing of microorganisms. Clin Infect Dis 1993, 17:153-162.

10. Carattoli A, Bertini A, Villa L, Falbo V, Hopkins KL, Threlfall EJ: Identification of plasmids by PCR-based replicon typing. J Microbiol Methods 2005, 63:219-228.

11. Sambrook J, Russel D: Molecular cloning: a Laboratory Manual. 3rd edition. New York, US: Cold Spring Harbor Laboratory Press; 2001.

12. Woodford N, Fagan EJ, Ellington MJ: Multiplex PCR for rapid detection of genes encoding ctx-m extended-spectrum (beta)-lactamases. $J$ Antimicrob Chemother 2006, 57:154-155.

13. Cloeckaert A, Praud K, Lefevre M, Doublet B, Pardos M, Granier S, Brisabois A, Weill FX: Inci1 plasmid carrying extended-spectrum-beta-lactamase gene blactx-m-1 in salmonella enterica isolates from poultry and humans in France, 2003 to 2008. Antimicrob Agents Chemother 2010, 54:4484-4486.

14. Bengtsson B, Greko G, Nilsson O, Landén A: Swedish Veterinary Antimicrobial Resistance Monitoring (SVARM) 2011. Uppsala: National Veterinary Institute (SVA); 2012

15. Bortolaia $V$, Bisgaard $M$, Bojesen AM: Distribution and possible transmission of ampicillin- and nalidixic acid-resistant Escherichia coli within the broiler industry. Vet Microbiol 2010, 142:379-386.

16. Persoons D, Haesebrouck F, Smet A, Herman L, Heyndrickx M, Martel A, Catry $B$, Berge AC, Butaye $P$, Dewulf J: Risk factors for ceftiofur resistance in Escherichia coli from Belgian broilers. Epidemiol Infect 2011, 139:765-771.

doi:10.1186/1751-0147-55-3

Cite this article as: Börjesson et al:: Spread of extended-spectrum betalactamase producing Escherichia coli isolates in Swedish broilers mediated by an incl plasmid carrying bla $a_{\mathrm{CTX}-\mathrm{M}-1}$. Acta Veterinaria Scandinavica 2013 55:3.

\section{Submit your next manuscript to BioMed Central and take full advantage of:}

- Convenient online submission

- Thorough peer review

- No space constraints or color figure charges

- Immediate publication on acceptance

- Inclusion in PubMed, CAS, Scopus and Google Scholar

- Research which is freely available for redistribution 